
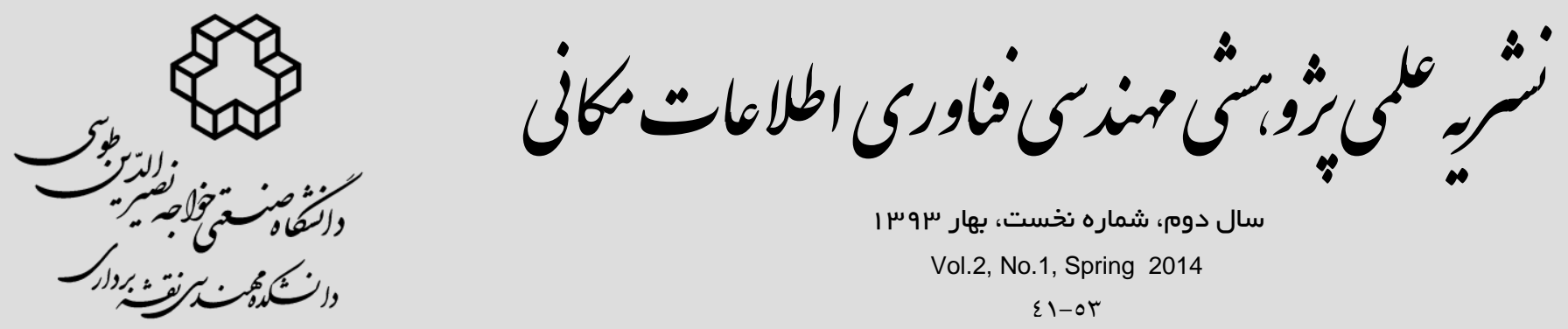

\author{
ارزيابى ميزان دادهاى هيدرو كرافى مورد نياز در عمقيابى ماهوارهاى

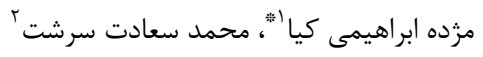

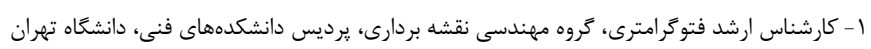

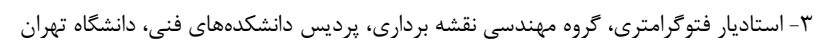

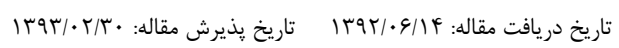

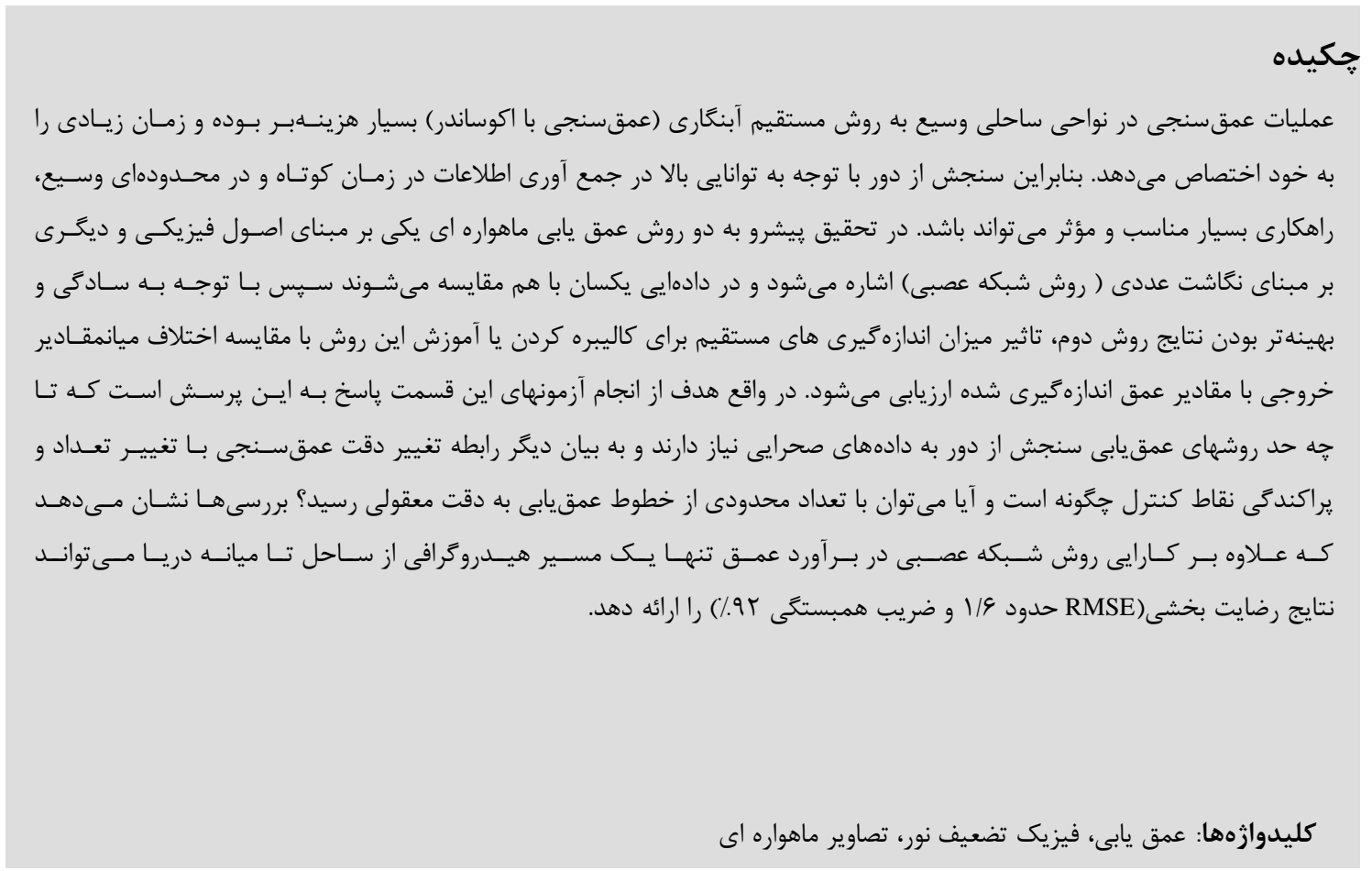

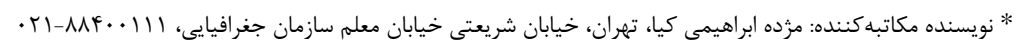

Email: moj_ebrahimikia@yahoo.com 
كاليبراسيون طيفى سـنجنده، تـوان تفكيـك طيفـى و

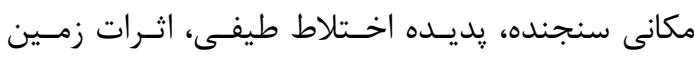

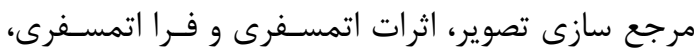
برق خورشيدى روى سطح آب، تلاطم آب، زاويـه ميـل

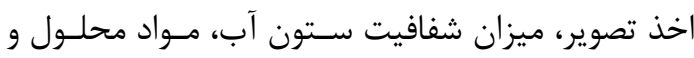

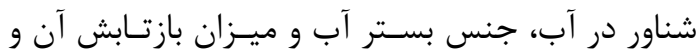

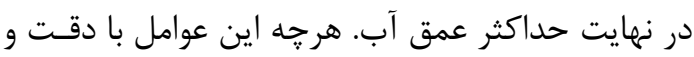

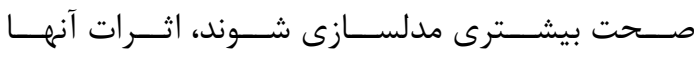

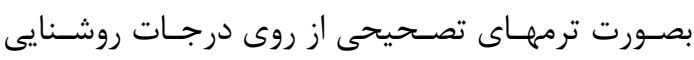

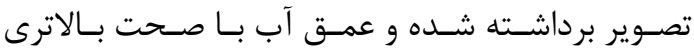
بدست مى آيد. مهمترين اين عوامل ميزان شفافيت و حداكثر عمق آب

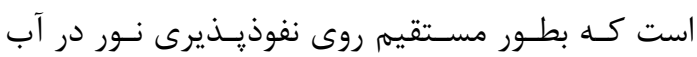

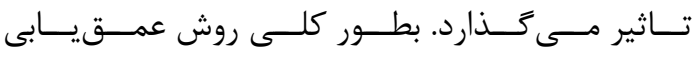

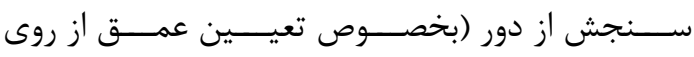

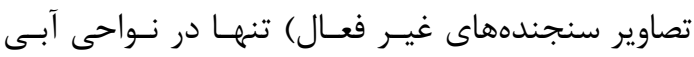

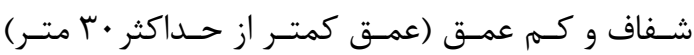

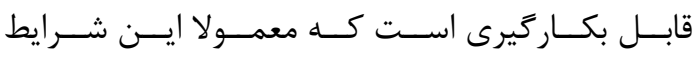
در درياجهها و سواحل دريـايى كسم عمـق وجـود دارد.

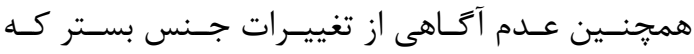
بهطور مستقيم روى شدت نور بازتاب يافته و در نتيجــه

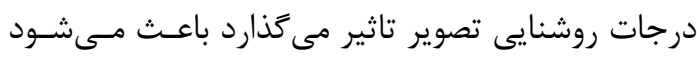
كه تخمين عمق آب با خطاهاى شديدى همراه شود.

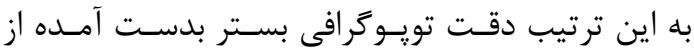

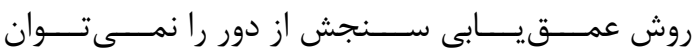

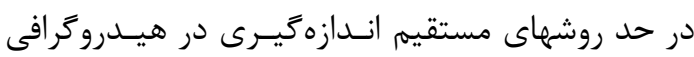

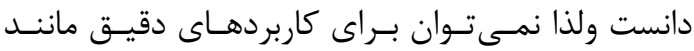

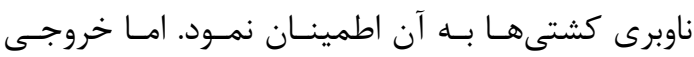

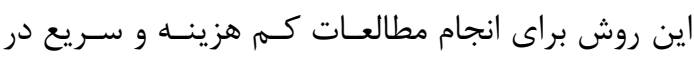

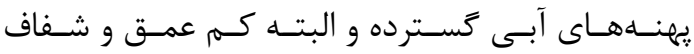

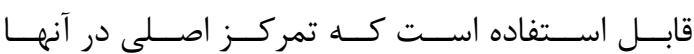
بررسى ساختار زئومورفولوزى بستر آب و نحوه تغييرات

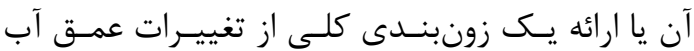

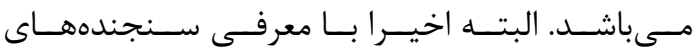

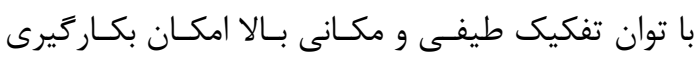

|- مقدمه

بطـور كلـى عمليـات عمـقـــنجى در نـواحى سـاحلى براى طلاع از اجزاى زير آب به منظور انجام فعاليتهـايى نظير كشتيرانى، لايروبى، قراردهى خطوط لوله و كابـل،

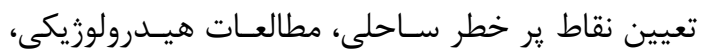

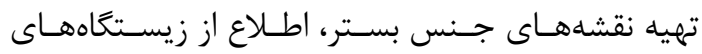
دريايى، جهت كاربرد در امور محسـيط زيسـت، نظـامى و

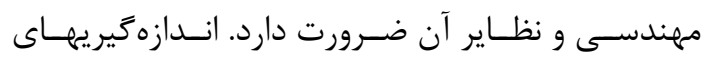

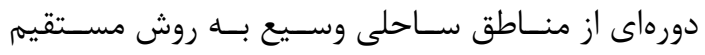
آبنغارى (عمقسنجى با اكوساندر) بسيار هزينهبر بوده و

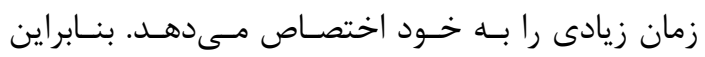

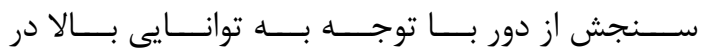

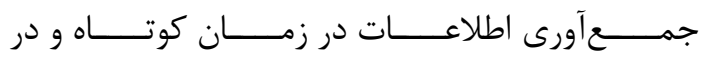

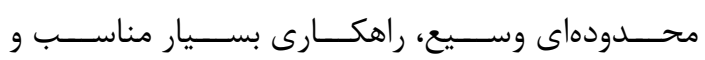

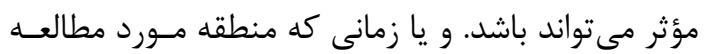

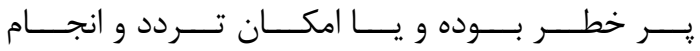

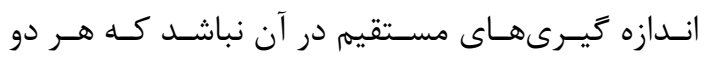

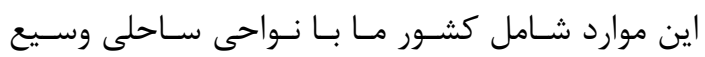

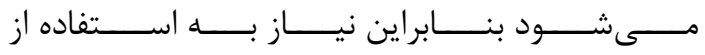

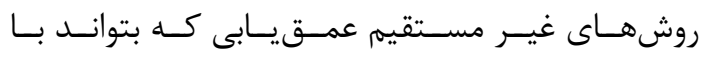

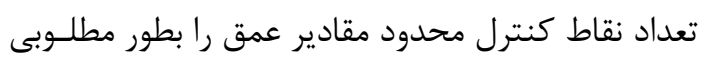

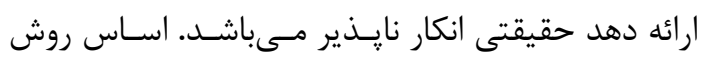

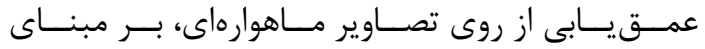

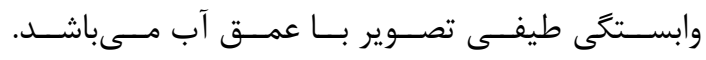

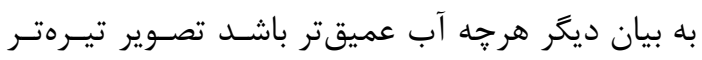

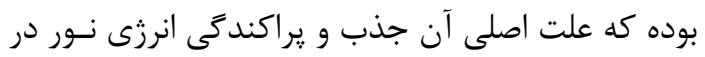

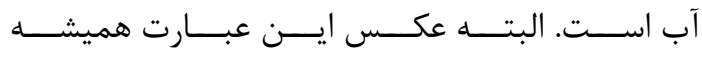

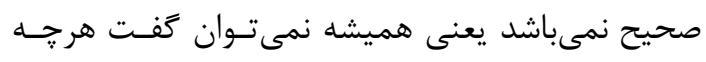
تصوير تيرهتر باشد، عمق آب بيشتر است.

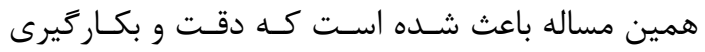
روش عمــقســنجى ســنجش از دور بــا محـدوديتههاى

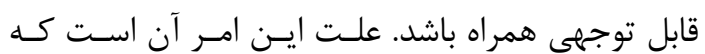
شدت درجات روشنايى تصوير علاوه بر ميزان عمـق آب

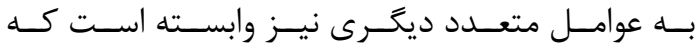

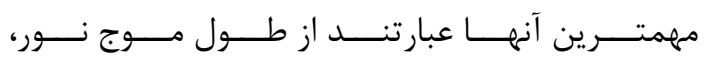


بطور كلى از مقدار راديانس بدسـت آمــده از آب عميـق

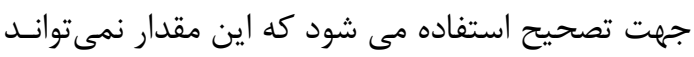

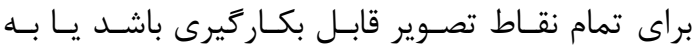

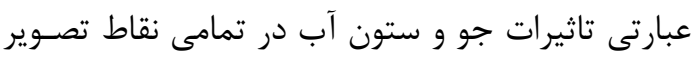
يكسان نيست.

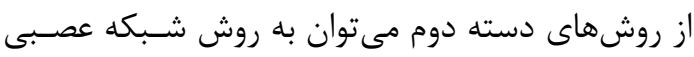

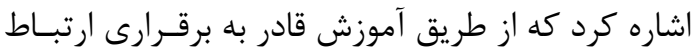

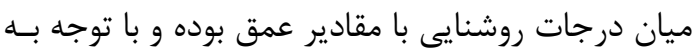

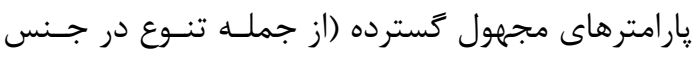
بستر و ستون آب) مى تواند راه حل سادهترى باشد.

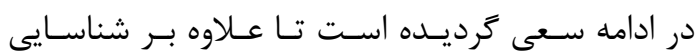

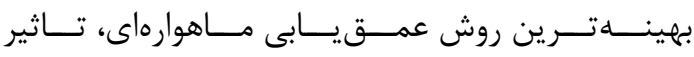

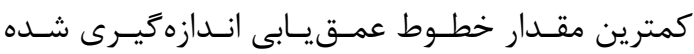

$$
\text { بر نتايج حاصل از آن ارزيابى شود. }
$$

\section{r- ادهادها و منطقه مورد مطالعه}

تصوير مـاهوارهاى مـورد اسـتفاده، تصـوير آيكونـوس از

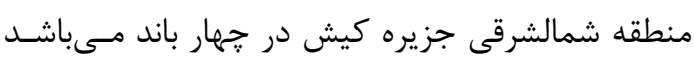

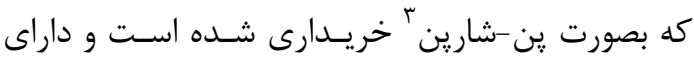

$$
\text { رزولوشن يك متر مى باشد. }
$$

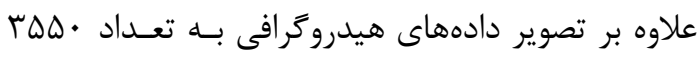

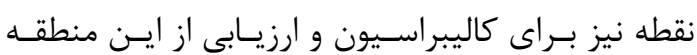

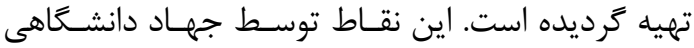

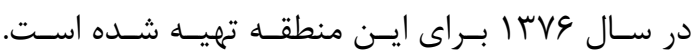

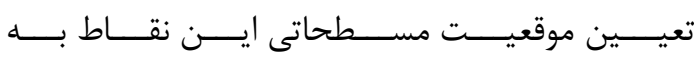

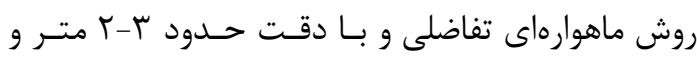

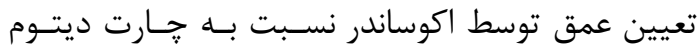

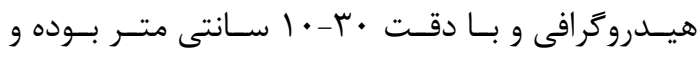

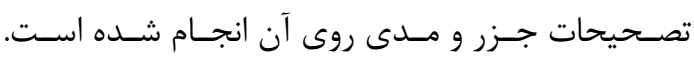

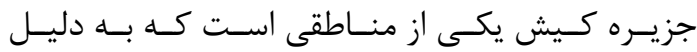

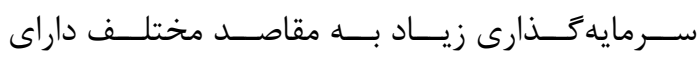

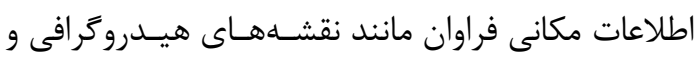

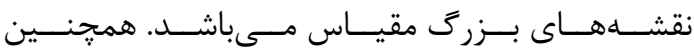

اين روش در نواحى كوخى مانند اسكلهها يا رودخانهها

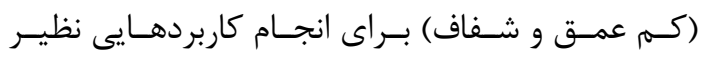

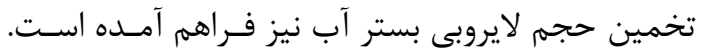

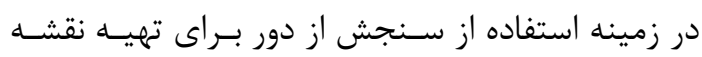
بستر آبهاى كم عمق روشهاى مختلفى ارائه شده اسـت. اكثر و نه تمام اين روشها را مى توان به دو دسـته كلى إلى

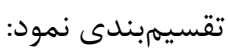

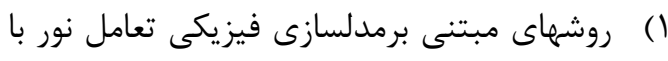
آب و محيط: كه در آن سعى شده مسير نور

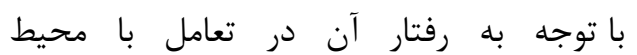

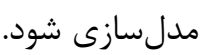
اين روشها كَاه بـر مبنـاى ثابـت بـودن شـرايط

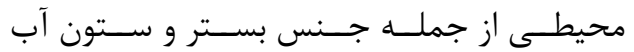

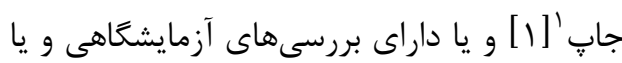

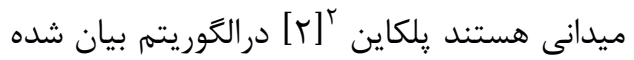

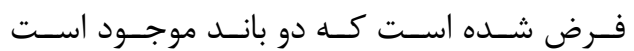

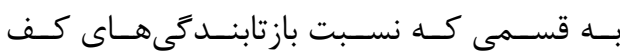

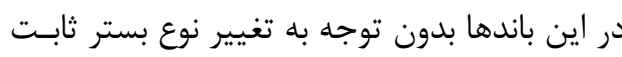

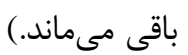
r) روشهاى مبتنى بر برازش تابع بين فضاى ورودى وخروجى: اين روشها بر مبناى ايجاد نكاشت بادي

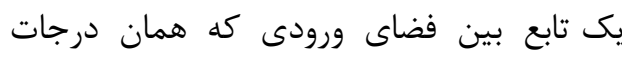
روشنايى و فضاى خروجى كه همان عمق است فئ مىباشند.

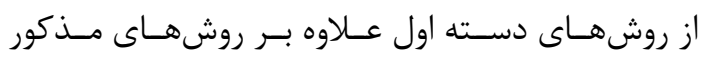

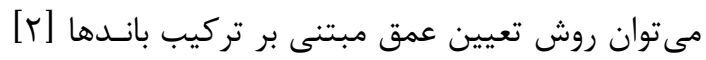

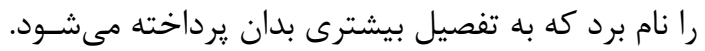

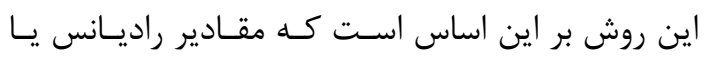

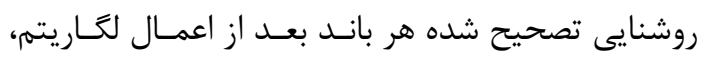

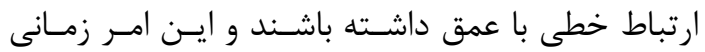
مهياست كه تصحيحات مربوط به اثرات جوى و سـتون آب بخوبى بر روى راديانس انجام كيرد. كه در اين روش وري 
كسم عمـق از كلاسـهاى محسدودى از جملـه مرجانهـا، جلبكها و ماسه تشكيل يافته است.
نواحى ساحلى اين جزيره از عمق تقريباً كم و شـفافيت

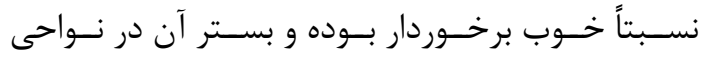

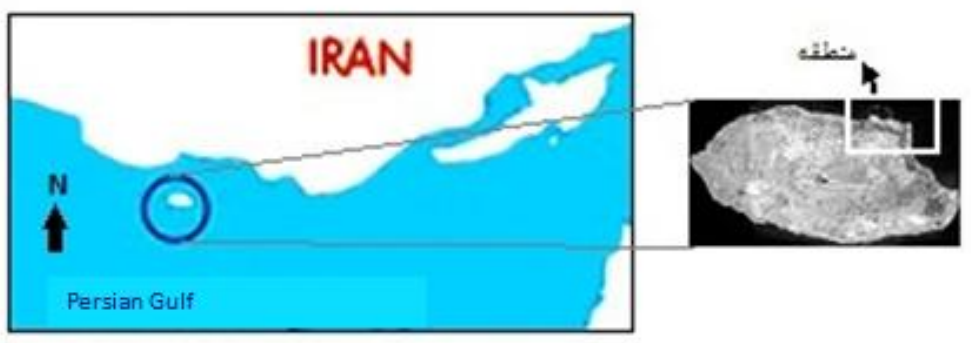

شكل ا: منطقه و تصوير مورد مطالعه

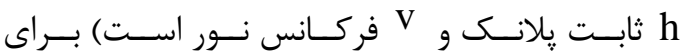

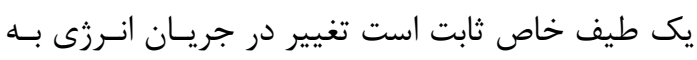

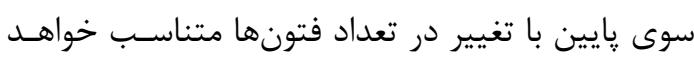
بود. همجنين شانس تضعيف با ضخامت جسمى كه نور از آن عبور مى كند افزايش مى يابد. با معلـوم بـودن

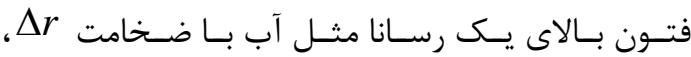

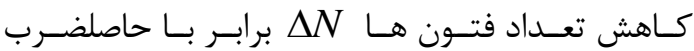

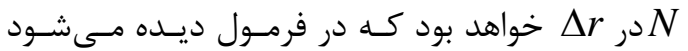
در اين فرمول ثابت تناسب $\alpha$ ضريب تضعيف مى باشد. $\Delta N=-\alpha N \Delta r$

رابطه (1)

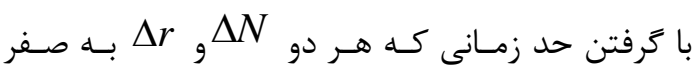

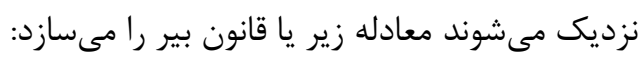
$\frac{d N}{N}=-\alpha d r$

$N(r)=N_{0} e^{-\alpha r}$

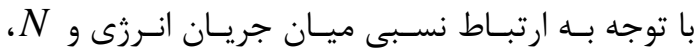

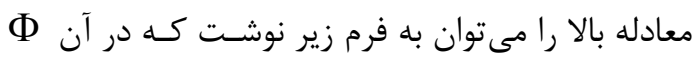

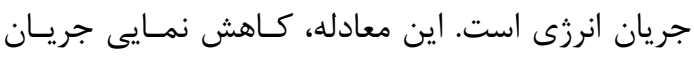

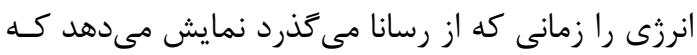

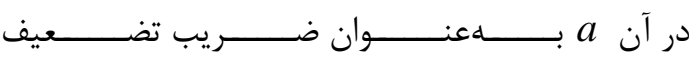

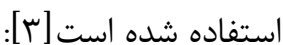

$\Phi(r, \lambda)=\Phi(0, \lambda) e^{-a(\lambda) r}$

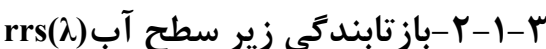

بازتابندكى زير سطح آب rs

بطــور كلـى فيزيكـى تضــيف نــور در آب و قـوانين

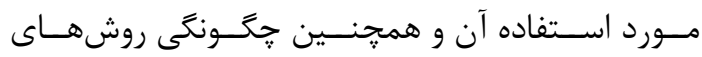
عمقيابى غير مستقيم در اين بخش بررسى مىشوند. r-ا- فيزيك تضعيف نور در آب

در اين بخش به نحوه و ميزان تضعيف نور هنكام كذر از

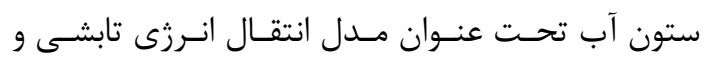

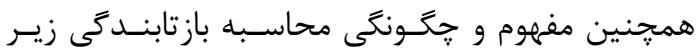
سطح آب در دو زير بخش جداءانه يرداخته مى وشود. r-1-1-مدل انتقال انرزى تابشى

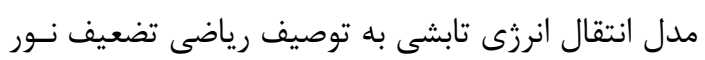
هنغام كذر از جسم آب مى يردازد. هنغامى كه فتونهـا

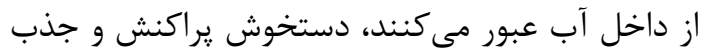

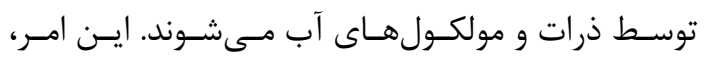

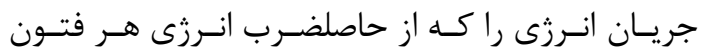

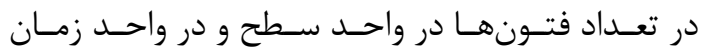

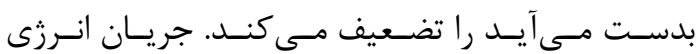

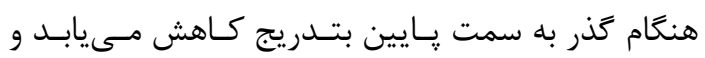

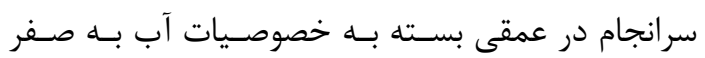
مىرسد. اين فرآيند تضعيف نور را مى بوان بان بان قانون بير'

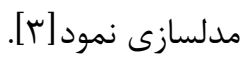

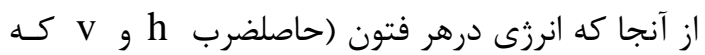




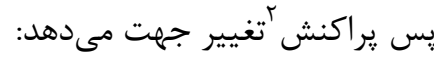

$$
\begin{aligned}
& E_{u w}(Z)=b_{b d}(Z) E_{d}(Z)
\end{aligned}
$$

رابطه (N)

$E_{u w}(Z \rightarrow 0)=E_{u w}(Z) \exp \left[-\int_{z}^{0} K_{u}(z) d z\right]$ ضر كه

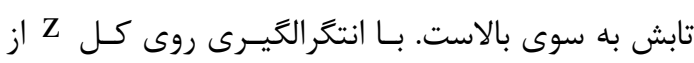

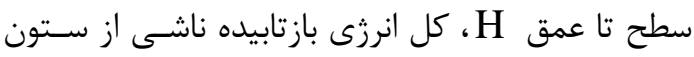

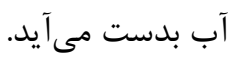

(رابطه 9)

$E_{u w}(0)=E_{d}(0) \int_{0}^{H} b_{b d}(Z) \exp \left[-\int_{0}^{z}\left(K_{d}(z)+K_{u}(z)\right) d z\right] d z$ انرزى بازتابيده از سطح بستر ناشى از انــرزى فـرودى و منعكس شده از آن در عمق H

رابطه (•) $E_{u b}(H)=A E_{d}(0) \exp \left[-\int_{0}^{H} K_{d}(z) d z\right]$

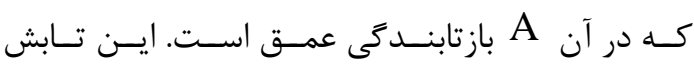
هنخام انتشار به سمت سطح تضعيف مىشود: رابطه (II) $E_{u b}(0)=A E_{d}(0) \exp \left[-\int_{0}^{H}\left(K_{d}(z)+K_{u}(z)\right) d z\right]$

2Backscatter

3Diffuseattenuationcoefficient
بازتابيده از آب به انرزى فـرودى در آب درسـت در زيسر

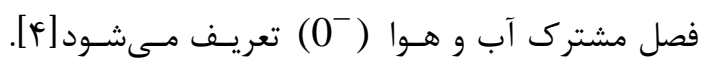

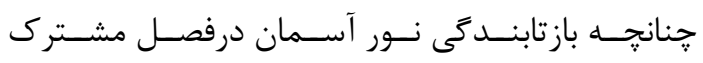

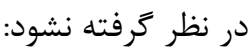

$\mathrm{r}_{\mathrm{rs}}(\lambda)=\mathrm{E}_{\mathrm{u}}\left(0^{-}, \lambda\right) / \mathrm{E}_{\mathrm{d}}\left(0^{-}, \lambda\right) \quad(\boldsymbol{\varphi})$ رابطه

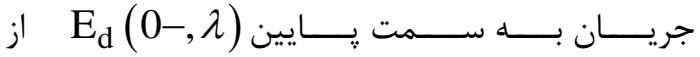

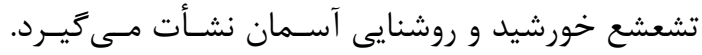

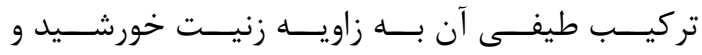

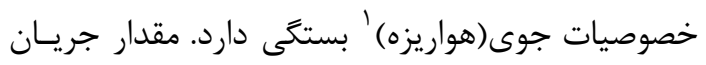

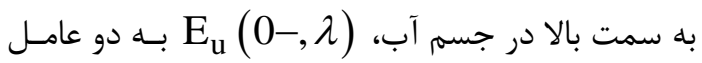

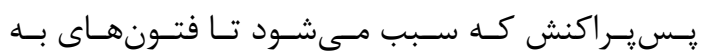
سمت بايين در حركت، به سمت عقب بركردند و عامـل

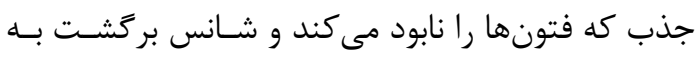

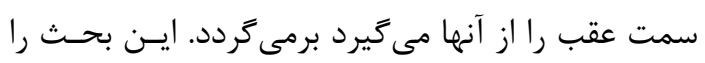
مىتوان به فرم زير بيان كرد:

$$
\mathrm{r}_{\mathrm{rs}}(\lambda)=\mathrm{f}\left[\mathrm{b}_{\mathrm{b}}(\lambda) / \mathrm{a}(\lambda)\right] \quad \text { (ब) }
$$

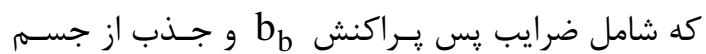

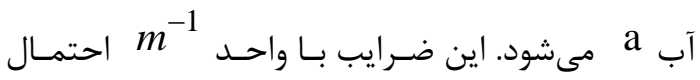
هس يراكنش و جذب در واحد طول را در امتداد مسـير

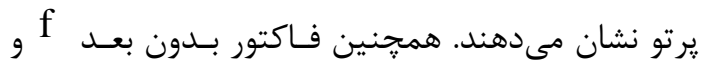

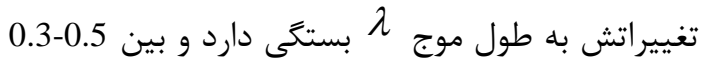

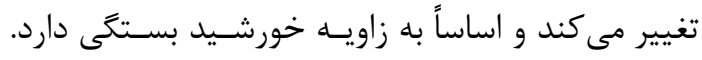
براى بيان دقيقتر اين بازتابندگى بهتر است تا سهمه هـر

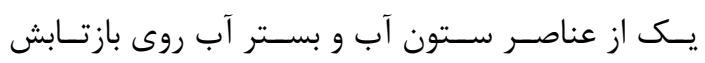

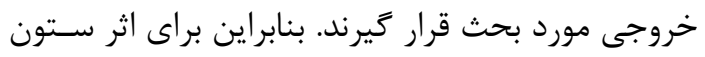

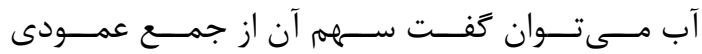

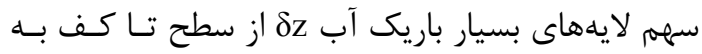
عمق H حاصل مىشود[ه]. در لايه

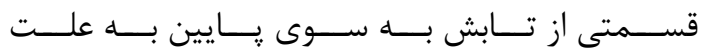

1Aerosol 
روش تصحيح جوى براساس اهداف تيره است. $\mathrm{X}_{\mathrm{i}}=\ln \left(\mathrm{L}_{\mathrm{i}}-\mathrm{L}_{\mathrm{si}}\right)$

رابطه (ه) در اين رابطه Li انرزى بازتابيـده ييكسـل در بانـد i و

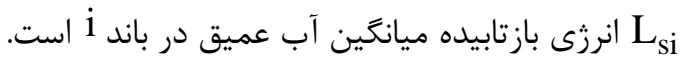

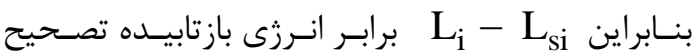

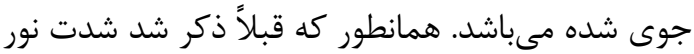

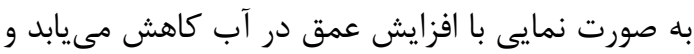

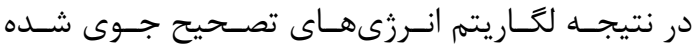
بهطور خطى با افزايش عمق كاهش مىيابند.

(L)

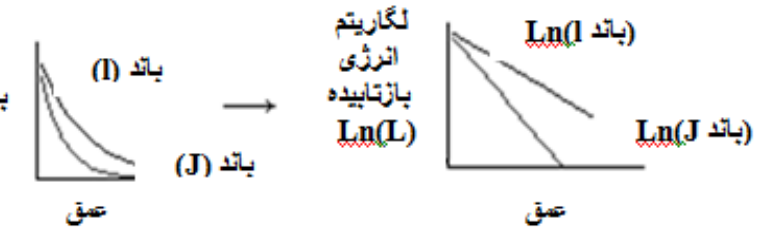

شكل ז: نحوه ارتباط انرزى باز تابيده و لعَاريتم آن با عمق [ع] بـا توجـهـ بــه ارتبـاط خطـى ميـان Xi بـا مقـادير Z Z

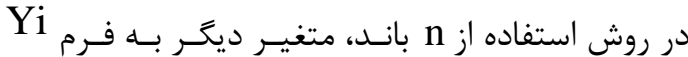
$Y_{i}=\sum_{j=1}^{N} A_{i j} X_{j}$ به صورت زير تعريف مىشود: رابطه (19)

كه از دوران سيستم مختصات مربوط به n متغير Xi

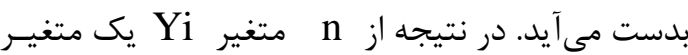

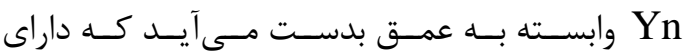

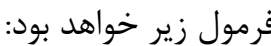
$\mathrm{Y}_{\mathrm{n}}=\mathrm{B}_{\mathrm{m}}-\mathrm{Cz}$ رابطه (IV) n-1 متغير ديخر غيـر وابسـته بـهـ عمـق و تـابعى از بازتابند تابعى از تركيبات بستر و C تنها به ضرايب تضعيف آب هئن

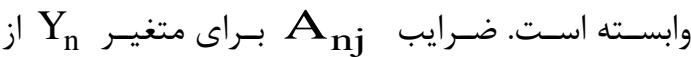
شــرايط متعامــد بــودن سيسـتم مختصــات جديــد و

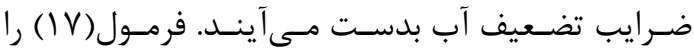
مىتوان به فرم سادهترى مطابق زير نوشت: $\sum_{j=1}^{N} A_{n j} X_{j}=\mathrm{B}_{\mathrm{m}}-\mathrm{Cz} \quad$ (|) رابطه

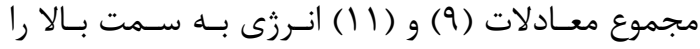
تشكيل مى مهد. با فرض آنكه ضرايب تضـعيف رخحـش و K باشــ $\mathrm{K}_{\mathrm{u}=} \mathrm{K}_{d}$ وابسته به تغيير عمق نباشند

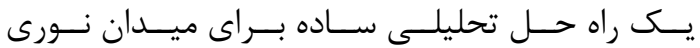
به سمت بالا در سطح بدست مى آيد:

رابطه (IT) $E_{u}(0)=E_{d}(0)\left[\frac{b_{b d}}{2 K_{d}}\left(1-\exp \left(-2 K_{d} H\right)\right)+A \exp \left(-2 K_{d} H\right)\right]$ براى آب عميق نسبت انرزى بازتابيده به انرزى فـرودى لـ

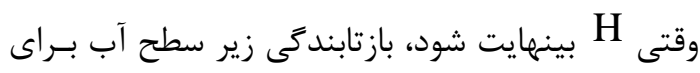
آب عميق تعريف مىشود (rs dp). آر اين شرط مرزى

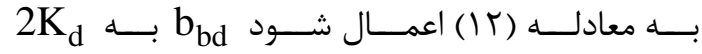

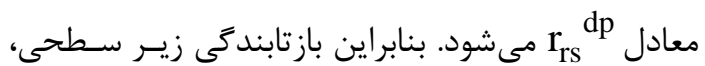

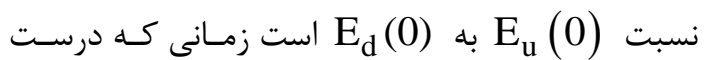

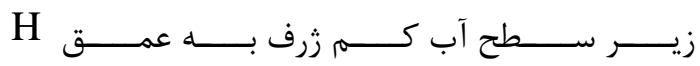

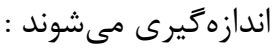
رابطه (1) $\dot{r}_{\mathrm{rs}}=\mathrm{r}_{\mathrm{rs}} \mathrm{dp}(1-\exp (-2 \mathrm{KH}))+\mathrm{A} \exp (-2 \mathrm{KH})$ رابطه (If) $r_{r s}=r_{r s}^{d p}+\left(A-r_{r s}^{d p}\right) \exp (-2 K H)$ ترم اول سـمت راسـت فرمـول (rاI) مربـوط بـه سـهمم ستون آب و ترم دوم مربوط به سهم كف آب است [ه]. r-r-روشهاى عمق سنجى مورد آزمون در اين بخـش بـراى هـر يـــ از روش هــاى فيزيكى و

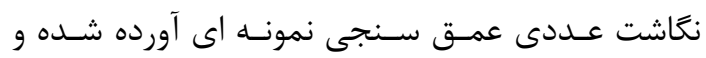
توضيح داده مىشوند.

r-r-1-روش تعيين عمق مبتنى بر تركيب باندها Lyzenga(1978) [r] Lyzenga نقشه جنس بستر دريا پيشـــهاد كـرده اسـت كـه تنهــا براى آبهاى شفاف نوع يكى يا دو مناسب اسـت. در ايـن 


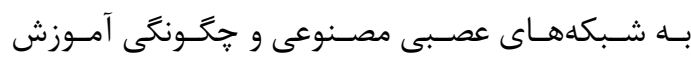
اين شبكهها را در كتب مرجع مانند [V] مطالعه نماييد. با توجه به اينكه اثبات شده است كه شــبكه يرســـترون با لايه ينهـان سـيخموئيد و لايسه خروجسى خطى يـى ئك

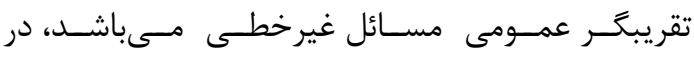

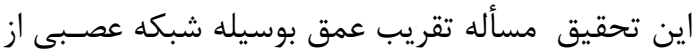

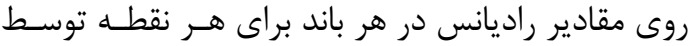
اين شبكه انجام گرفته است. روتير

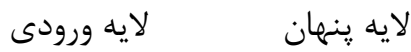

$$
\begin{aligned}
& \mathrm{z}=\mathrm{a}_{0}+\mathrm{a}_{1} \mathrm{X}_{1}+\mathrm{a}_{2} \mathrm{X}_{2}+\ldots+\mathrm{a}_{\mathrm{n}} \mathrm{X}_{\mathrm{n}} \quad \mathrm{l}
\end{aligned}
$$

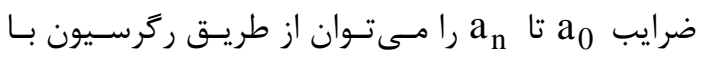

شبكههـاى عصـبى مصـنوعى از اتصـال وزنـدار عناصـر

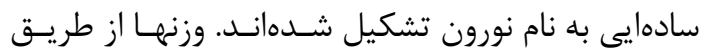
ارتباط ميـان جفـت مقـادير ورودى و خروجسى معلـوم در فرآيند آموزش شبكه بدست مي آيند. جزئيات مربوط لايه خروجى لنريات

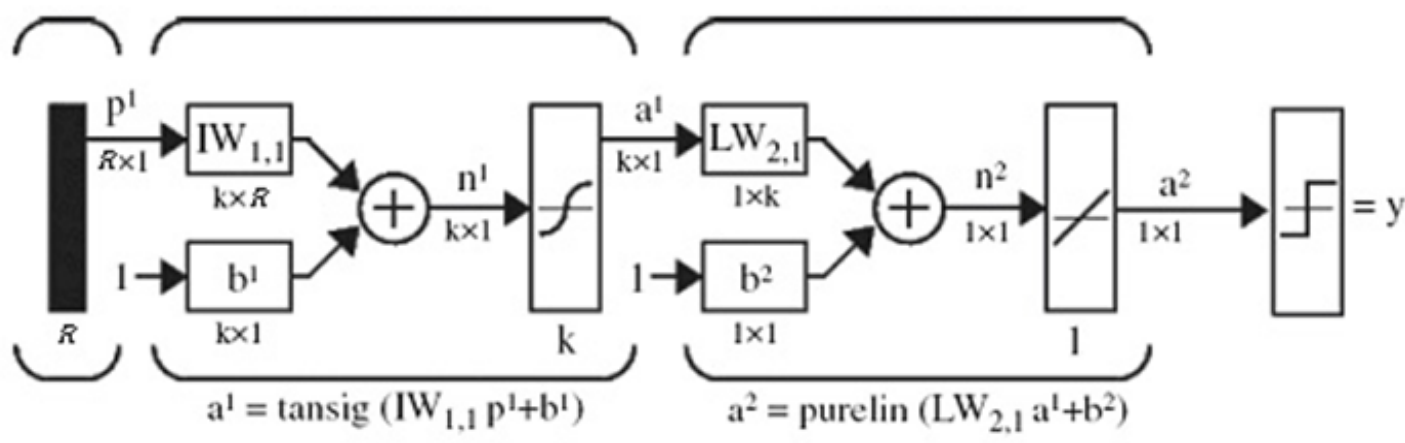

شكل r: شبكه مورد استفاده در تقريب تابع تعيين عمق[•!]

و مكانى نقاط كنترل با توجه به تراكم آنها مىشود.

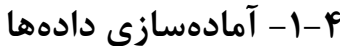

جهـــت اســتخراج واقعــى تــــر اطلاعـــات عمـــق از

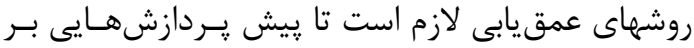

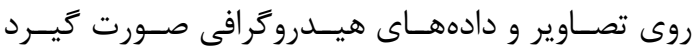

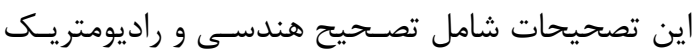

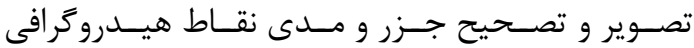
مىباشد. جهت تصحيح هندسى از نقشه بزرى مقيـاس

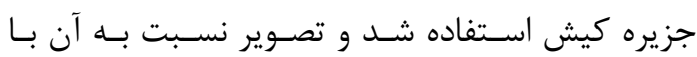
انتخاب نقـاط مشـترك و اسـتفاده از معـادلات رشـــال هم مرجع شد سيس با تهيه ماسكى باينرى نواحى آبسى از نواحى خشكى جداسازى شد. مقادير عمقيـابى شــده

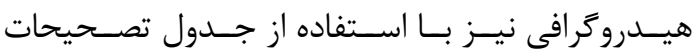
جزر و مدى نسبت به زمان تصوير بردارى تصحيح شـد
در اين شبكه R ورودىهــا يـا مقــادير راديـانس بــراى هر نقطه در هر باند و K تعداد نورونهاى لايه ينهـان و و

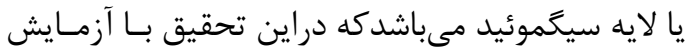
مقدار بهينه آن بدست آمده است. بدينمنظور با استفاده

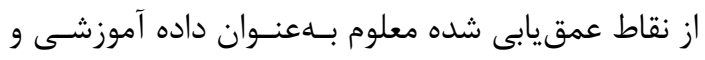

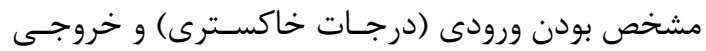

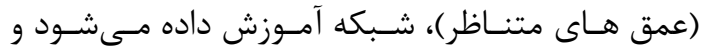

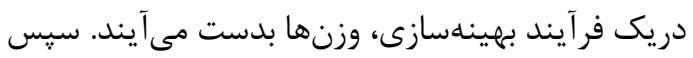

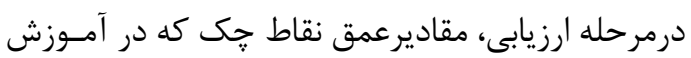
شركت نكردهاند با استفاده از اين شبكه بدست مى آيد و با مقادير واقعى آنها مقايسه مىشود.

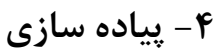
اين بخش شامل آماده سازى دادههـا، ارزيـابى روشـهاى

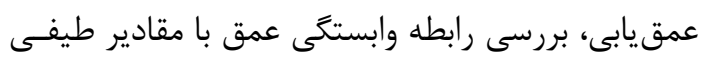



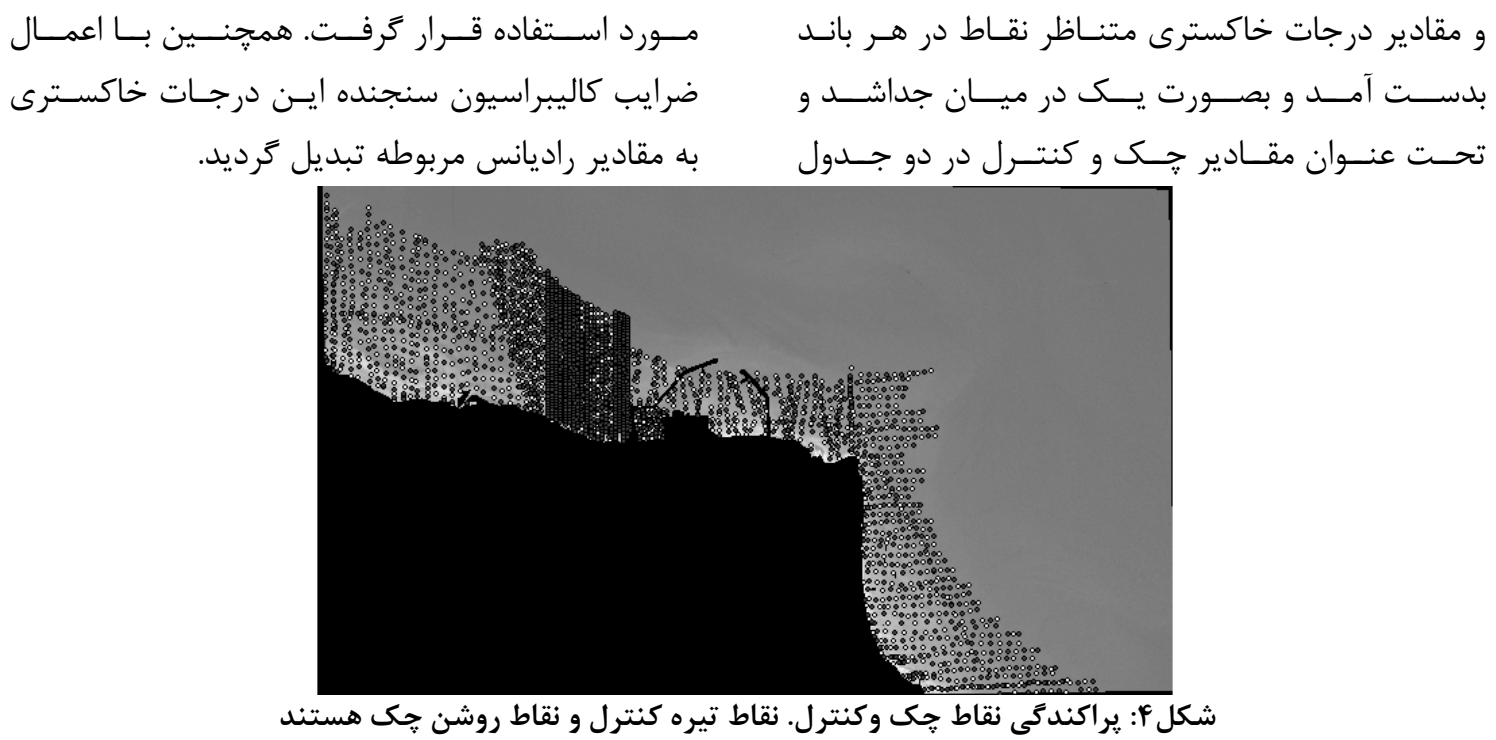

$$
\text { تدريج كاهش داده مى شود. }
$$

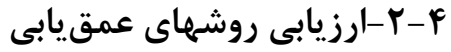

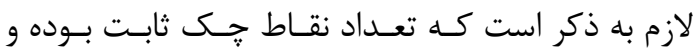
مقدار عمق نقاط جى توسط دادههاى مكـانى و طيفى

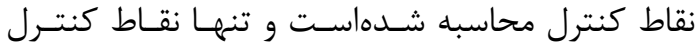

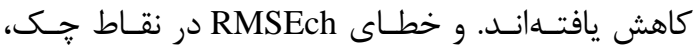
حداكثر خطاى قدرمطلق، ميزان همبستتى ميان عمـق ونق

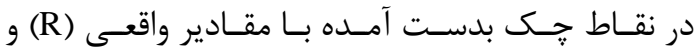
متوسط قدر مطلق ده خطاى حداكثر ارائه شده است: اين آزمونها در شش مرحله بصورت زير انجام يذيرفت:

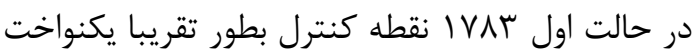

با تراكم متوسط هی متر بكار زرفته شده است.

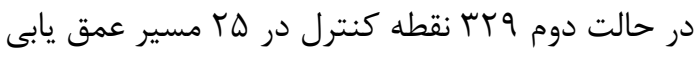

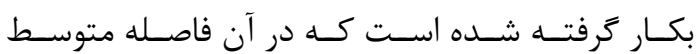
مسيرهاى عمقسنجى ·rV متر است.

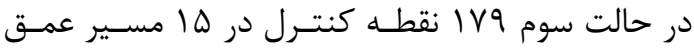

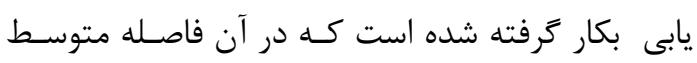

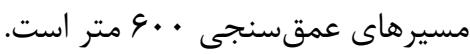

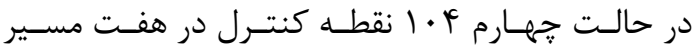

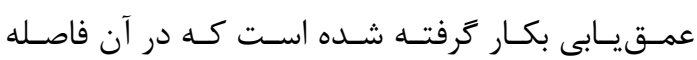
متوسط مسيرهاى عمقسنجى · · fl متر است. در حالت ينجم V Vقطه كنترل در سه مسير عمق يابى

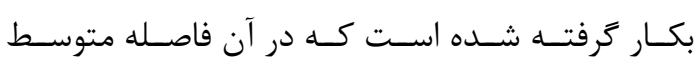
مسيرهاى عمقسنجى . . . م متر است.

نتايج حاصل از اين دو روش بر روى نقاط جـك مطــابق

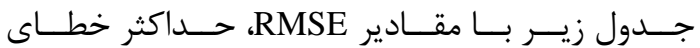

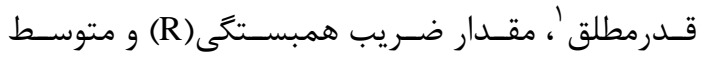

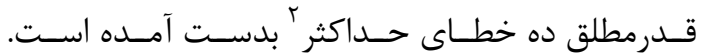
در تمامى نمودارهاى نتايج (شـكله و و

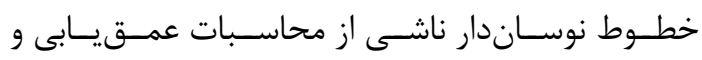
خط ممتد مقادير اندازهزيرىشده مىباشد.

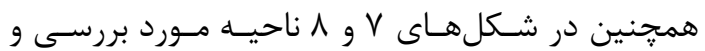
9 حاصل از عمق يـابى هيـدروگرافى و در شـكل DSM

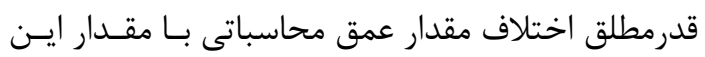

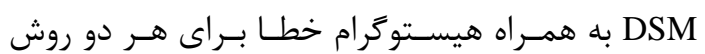
نشان داده شده است.

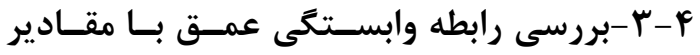
طيفى و مكانى نقاط كنترل با توجه به تراكم آنها در اين آزمون بررسى مىشود كه بـراى عمـق يـابى بـهـ

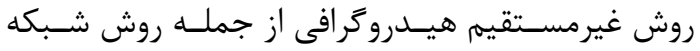

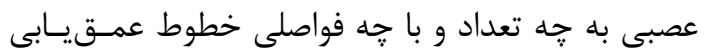

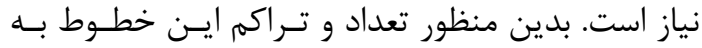

1 MaxError

2 MATE 
نقاط كنترل را نشان ميدهد. همجنين شكل II 1 تعداد و يراكندگى نقاط جك را نشان مى دهد.
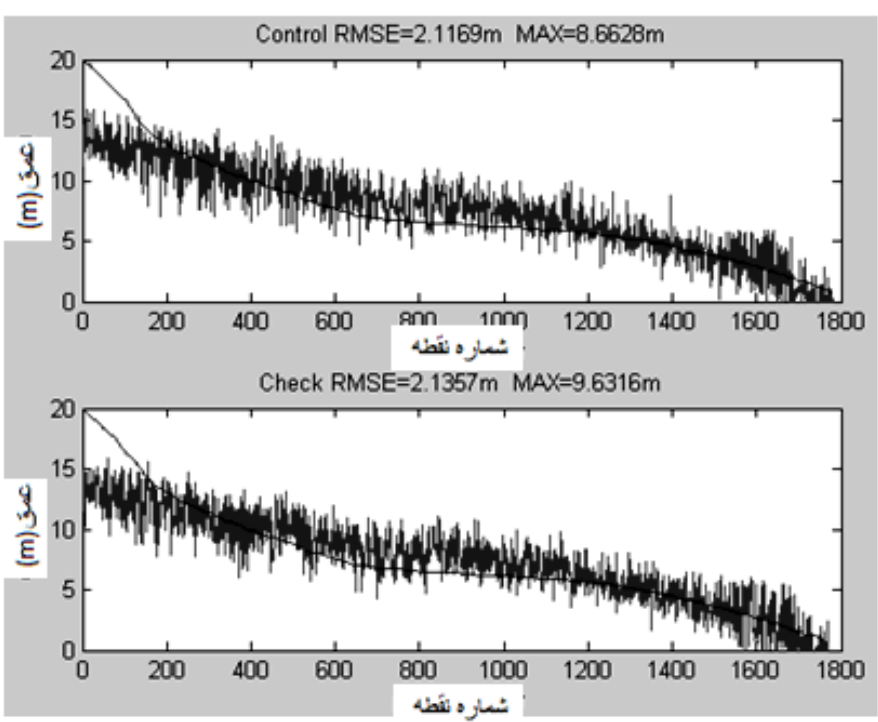

در حالت ششم ب ب نقطـهـ كنتــرل در تنهـا يـك مسـير عمق يابى بكار كرفته شده است.

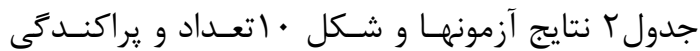

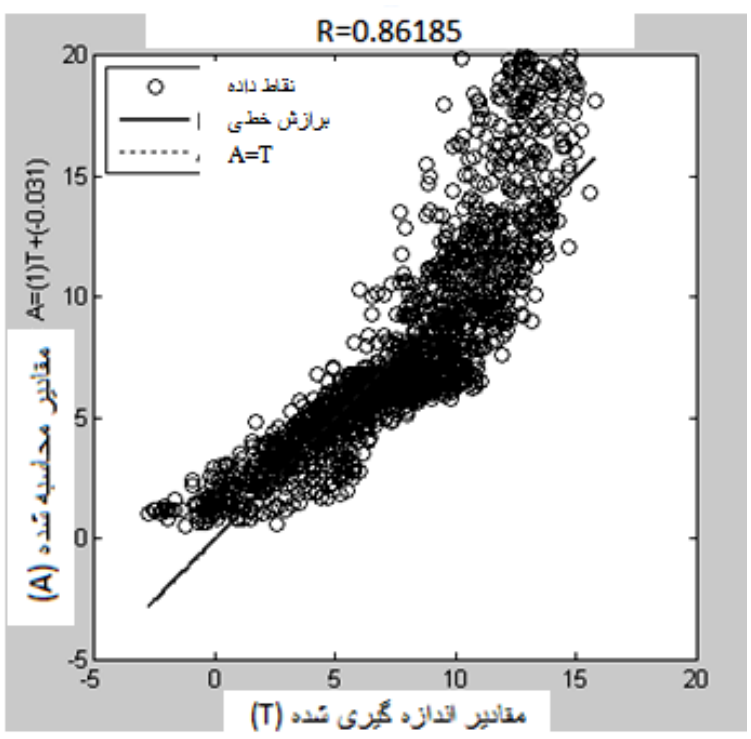

شكله: نتايج روش Lyzenga روى دادهاى راديانس
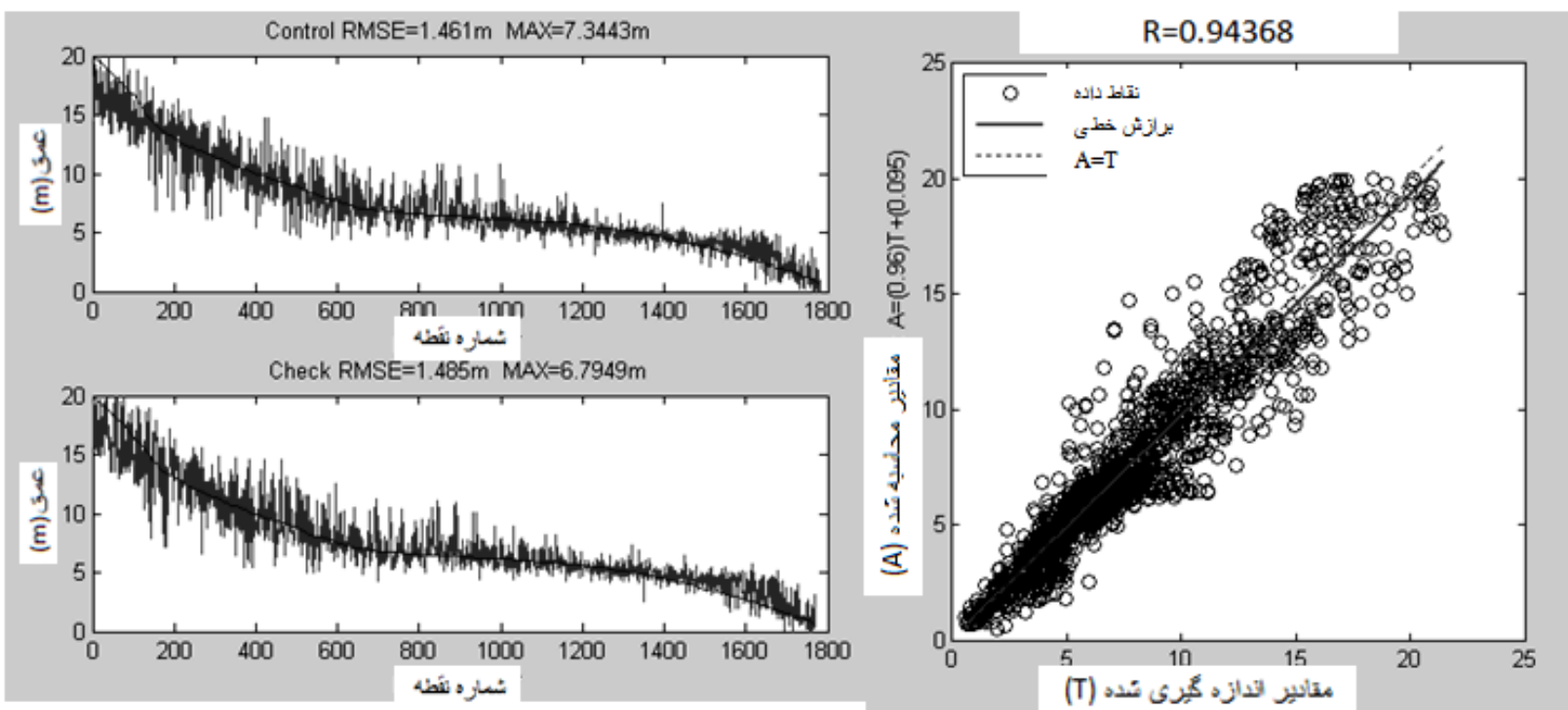

شكل \&: نتايج اعمال روش ANN روى درجات روشنايى جهار باند

جدولا: نتايج اعمال روش ANN و روش Lyzenga

\begin{tabular}{|c|c|c|c|c|c|c|}
\hline مه خطاى حدرمطلق حداكثر & هقدار ضريب & حداكثر خطاى & RMSE & \multicolumn{3}{|c|}{ روشهاى عمق يابى سنجش از دور مورد آزمون } \\
\hline V.ఎ9 & $\cdot .19$ & 9.94 & T.IF & روى مقادير راديانس & 1 & روش Lyzenga \\
\hline$\Delta . \Delta r$ & .94 & 9.19 & $1.4 \wedge$ & روى مقادير درجات خاكسترى جهار باند & $r$ & روش ANN \\
\hline
\end{tabular}




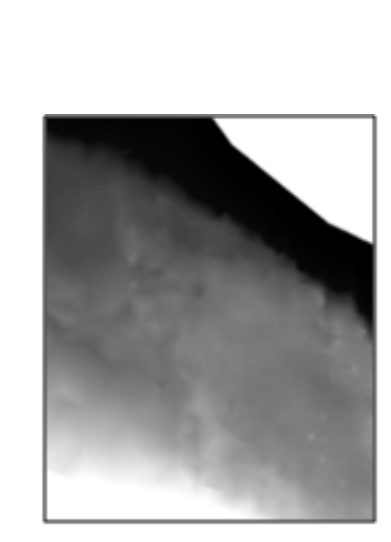

شكل 1: نمايش DSM بدست آمده

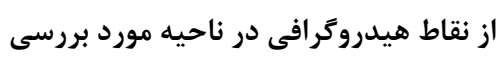

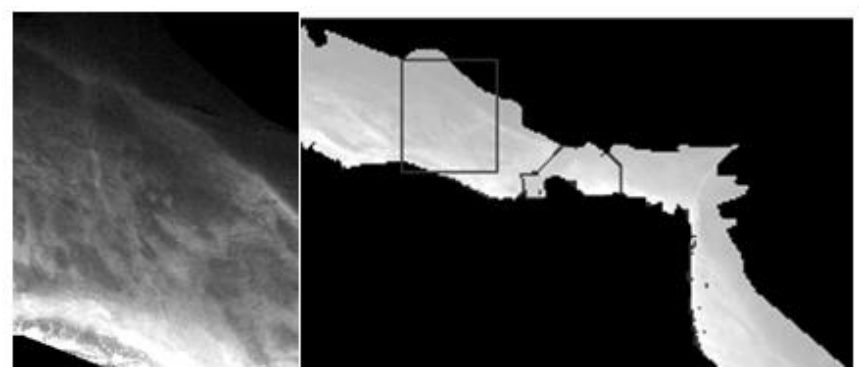

شكل \:نمايش ناحيه مورد بررسى

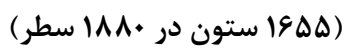

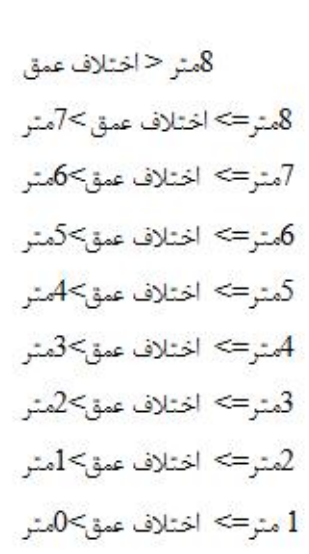

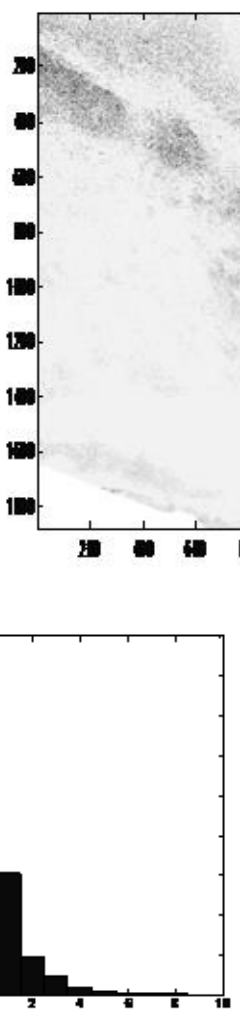

$\mathrm{ANN}$
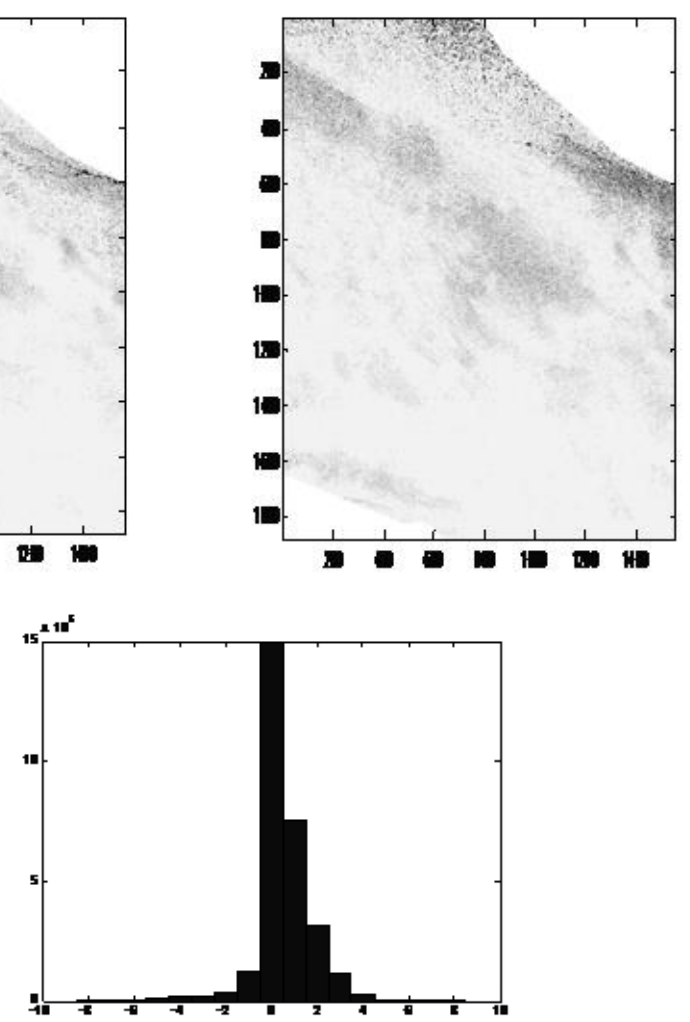

Lyzenga

شكل 9: نمايش توزيع مكانى و هيستوكرام خطاهاى روشهاى عمق يابى

جدول r: آزمونهاى كاهش تدريجى مسيرهاى عمق يابى هيدروكرافى (واحد به متر )

\begin{tabular}{|c|c|c|c|c|c|}
\hline متوسط قدرمطلق ده حداكثر & $\mathbf{R}$ & حداكثر خطاى & RMSEch & حالت & روش تخمين عمق \\
\hline$\Delta . f^{F}$ & .94 & G.rT & $1 . \mathrm{FV}$ & اول & \multirow{6}{*}{ آموزش شوش عمق يابى بر مبنـاى } \\
\hline 0.99 & $\cdot .94$ & $9.9 \mathrm{~V}$ & $1.8 \wedge$ & دوم & \\
\hline$\Delta .90$ & .94 & 9.19 & 1.199 & سوم & \\
\hline$\Delta . V F$ & .94 & $9 . \Delta \Delta$ & 1.49 & جهارم & \\
\hline 9.Ar & $.9)^{f}$ & V.V9 & 1.90 & ينجم & \\
\hline D.FF & $.9 r$ & Q.AV & 1.99 & ششم & \\
\hline
\end{tabular}




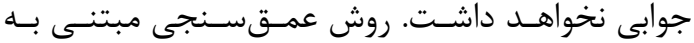

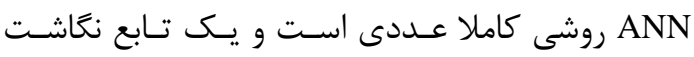
ضمنى را از درون دادههاى كنترل اسـتخراج مسى كنـد،

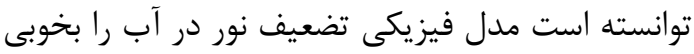

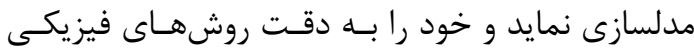

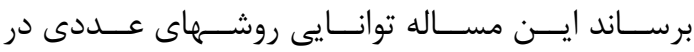
هوش مصنوعى را نشان مى دهد.

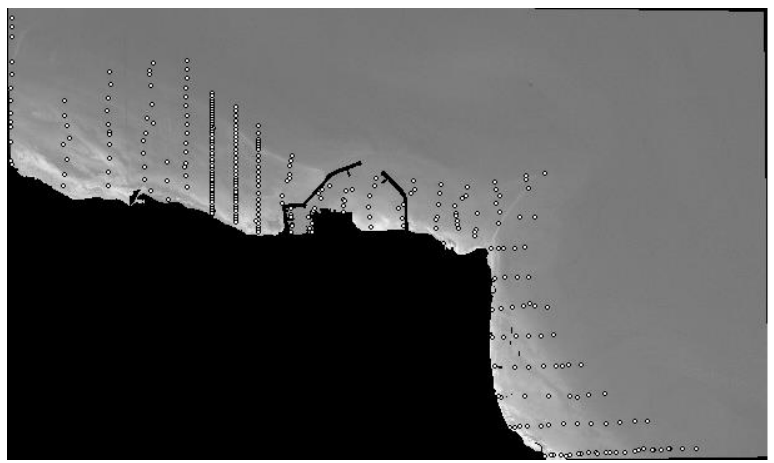

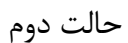

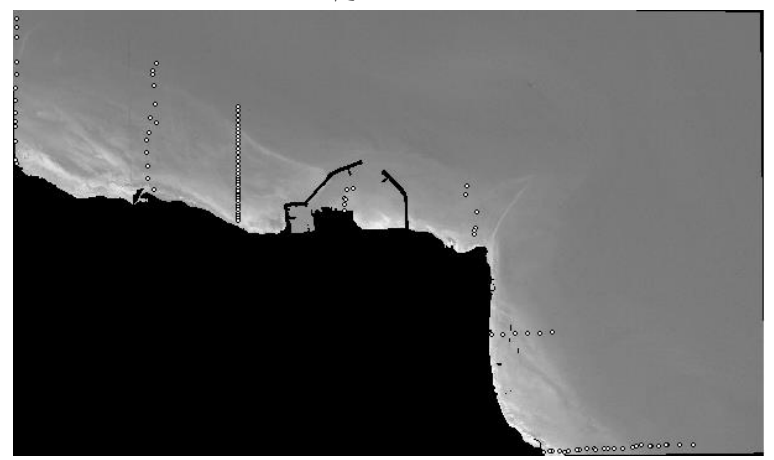

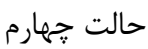

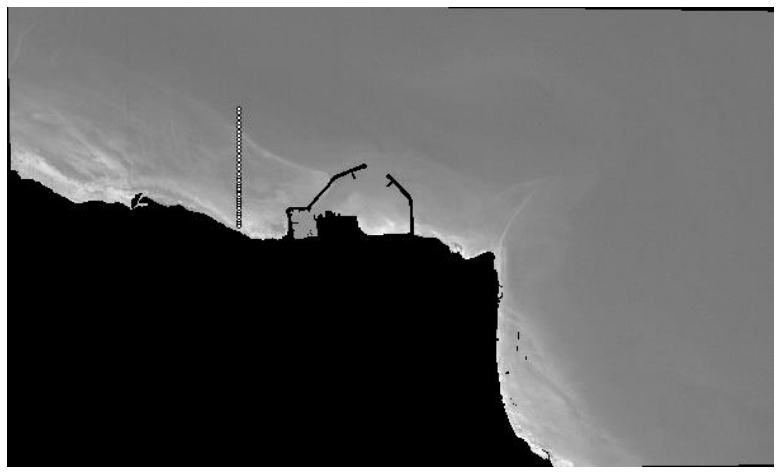

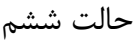

$$
\text { ه- نتايج }
$$

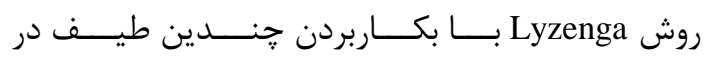

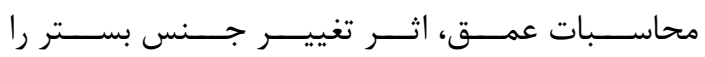

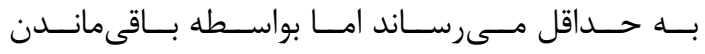

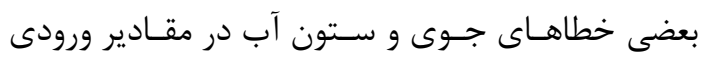

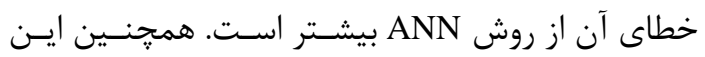

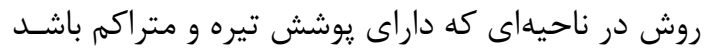

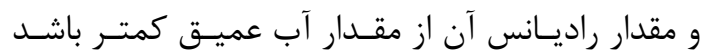

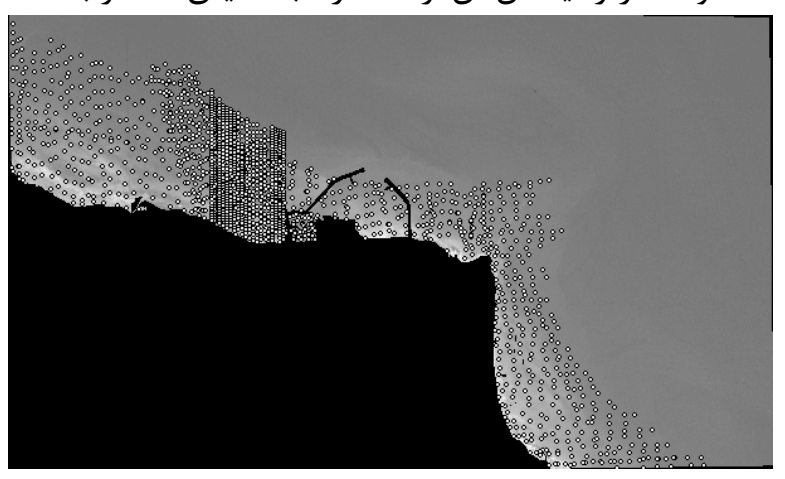

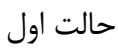

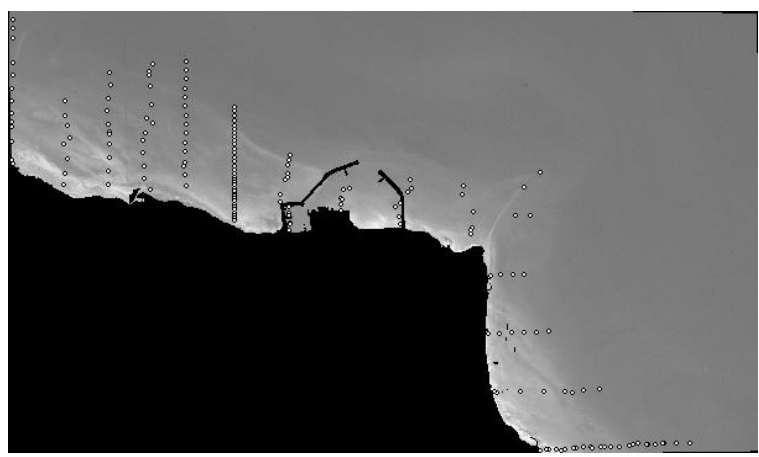

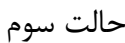

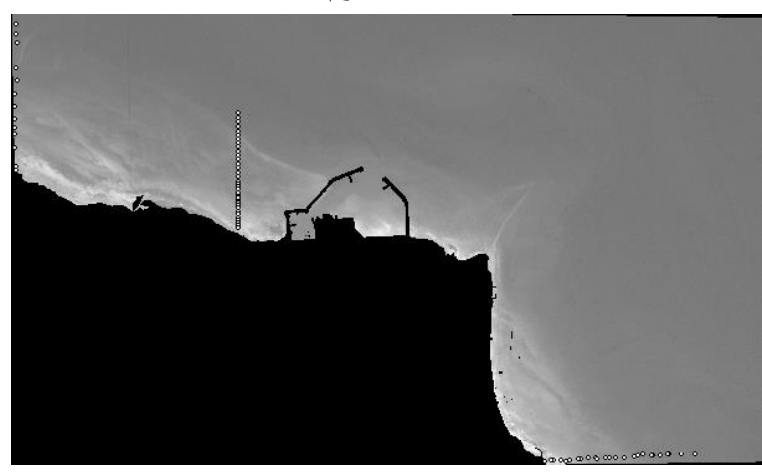

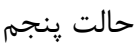

شكل •1 : تعداد و يراكندكى نقاط كنترل با كاهش مسيرهاى عمقيابى هيدروترافى 


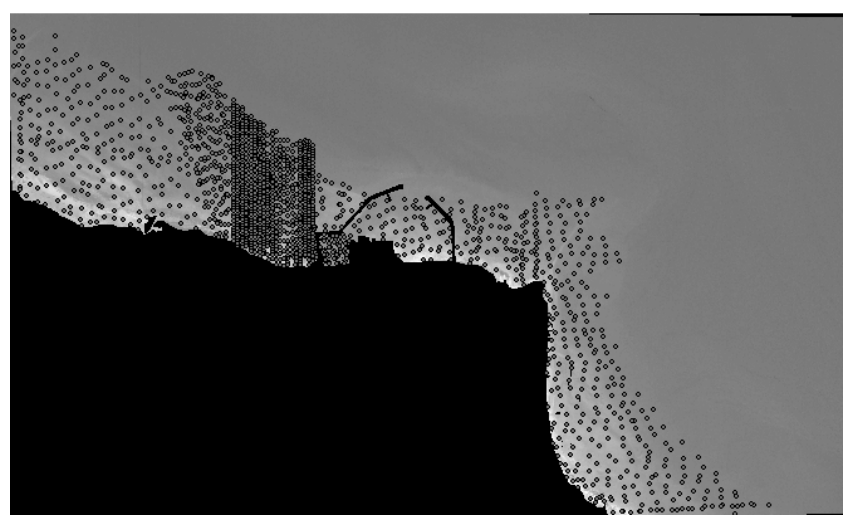

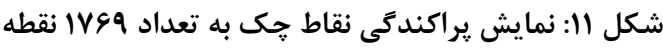

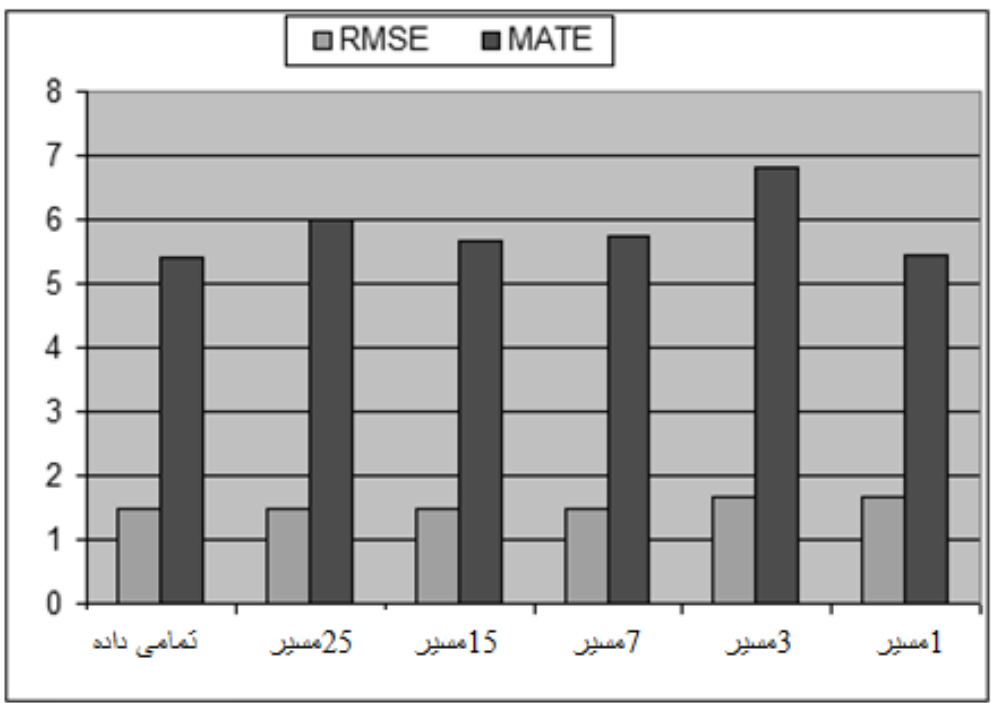

شكل זا: تاثير تعداد مسيرهاى عمقسنجى بر كيفيت نتيجه نهايى

عمقسنجى بكونهاى طراحى شوند كــه اعمـاق مختلـف

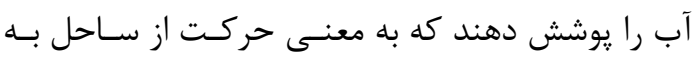
ميانه دريا است.

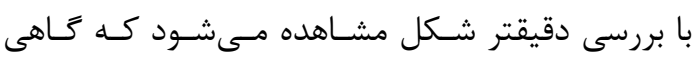

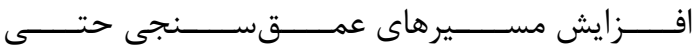
موجب كاهش جزئى دقت نتيجه نهايى مسىشـود. يـك

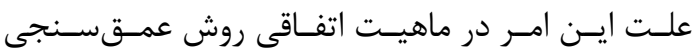
بكار رفته در اين آزمونها يعنى روش عمقسنجى مبتنى ماسي

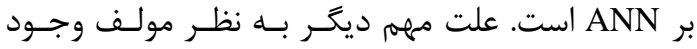
الكوى مكانى خطا در منطقه است كه ناشى از تغييـرات

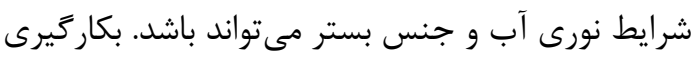

اما بزر گتـرين ضـعف ايـن روش نايايسدارى آن اسـت و

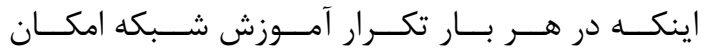

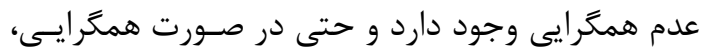

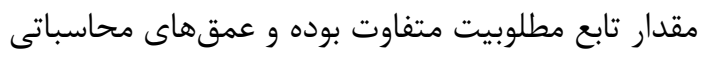
مقادير متفاوتى در هر تكرار هستند معد مئد

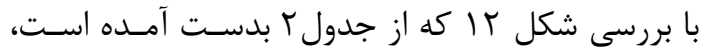

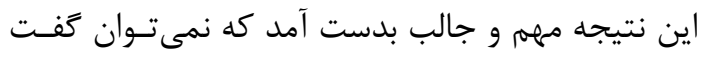
افزايش تعداد مسيرهاى عمـقســنـى موجـب افـزايش دقـت نتيجــه نهـايى مسى شـود و بنـابراين يـك مســير عمقسنجى براى جمعآورى نقاط كنتـرل كـافى اسـت.

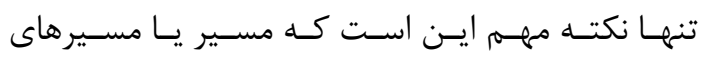




$$
\begin{aligned}
& \text { از روش ساده آموزش شبكه عصـبى و اسـتفاده از تنهـا }
\end{aligned}
$$

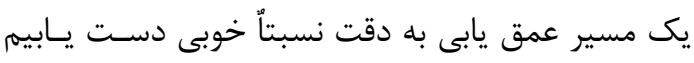

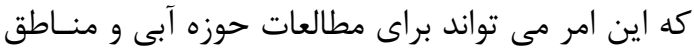

$$
\begin{aligned}
& \text { ير خطر و وسيع مفيد و موثر باشد. }
\end{aligned}
$$

[1] Edwards, A.j., Crude bathymetric mapping using Landsat TM Satellite imagery . Application of satellite and airborne image data to coastal management.Thematic modules and lessons.http://www.noc.soton.ac.uk/bilko/ Access:12/1/2009

[2] Lyzenga, D. R.1978. Passive remote sensing techniques for mapping water depth and bottom features. Applied Optics. Vol. 17, No. 3

[3] Bukata, R.P., Jerome, J.H., Kondratyev, K.Y.and et al, 1995, Optical Properties and Remote Sensing of Inland and Coastal Waters. Florida, CRC Press, Boca Raton.

[4] Edwards, M,P.,A.Environment and development in coastal regions and in small islands. Coastal management sourcebooks 3. Part 2 The Acquisition, Correction and Calibration of Remotely Sensed Data.http://www.unesco.org/csi/pub/source/r s10.htm .Access:4/8/2008

[5] [Werdell, P. J., Roesler, C. S. 2003. Remote assessment of benthic substrate composition in shallow waters using multispectral reflectance. Limnol.Oceanogr., 48(1, part 2), 557-567

[6] Jerlov, N.G., 1951, Optical Studies of Ocean Water. Report of Swedish Deep-Sea Expeditions 3, 73-97.

[7] Bill, R., Jackson, T., Translator: Alborzi, M., Familiarity with neural networks. Sanati

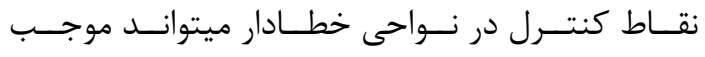

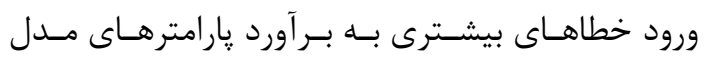

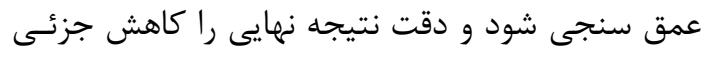

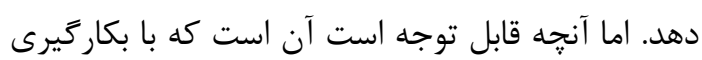

$$
\begin{aligned}
& \text { ^- منابع }
\end{aligned}
$$

Sharif University Science publication Ins (Persian).

[8] Edwards, A.j.,1998, Crude bathymetric mapping using Landsat TM Satellite imagery. Application of satellite and airborne image data to coastal management. France: Unesco's workshops, 103-120

[9] Alpers, W., Campbell, G., Wensink, H., and et al.1997. Chapter 10. Underwater

Topography. Graduate college of Marine studies, University of Delaware, Newark, DE, USA. 245-262

[10] Matlab Microsoft 2007.mathworks inc.

[11] Jupp, D.L.B., 1988, Background and extensions to depth of penetration (DOP) mapping in shallow coastal waters. In: Symposium on Remote Sensing of the Coastal Zone. Gold Coast, Queensland, IV.2.1-IV.2.19.

[12] Antoine, Q., 2005, Chapter 3 depth determination. Manual on Hydrography., International Hydrographic Bureau4. 119198. 


\title{
The Assessment of Required Hydrographic Data for Remote Sensing Bathymetry
}

\author{
Ebrahimi kia, M. ${ }^{* 1}$, Saadat Seresht, M. ${ }^{2}$ \\ 1-Ms.c of Photogrammetry in Department of Geomatics, College of Engineering, University of Tehran \\ 2- Assistant professor in Department of Geomatics, College of Engineering, University of Tehran
}

\begin{abstract}
Today, depth mapping of coastal and waterfront areas is necessary for various aims such as shipping, dredging, underwater piping, hazardous area detection, hydrological studies, material mapping of water bed, information collection from marine settlements for environment preservation, military and engineering applications. Periodical depth mapping of wide water areas by classic hydrographic method (via ecosounder) is expensive and time consuming. Therefore, due to high capability of remote sensing in rapid data collection from wide area, it can be an effective and proper complementary method for this purpose. Attention to this issue is more important for our country which has long shorelines. At this paper two physical and mathematical bathymetric methods are evaluated. The first method is based on physical behaviour of light attenuation in water column while the second method is a numerical fitting between image gray levels and according water depths by means of artificial neural network (ANN). Our initial experiments show that although the first method has physical meaning but the second method is more accurate and simpler too. Both methods require a set of known hydrographic depthes as calibration data. Therefore, our next experiments try to answer two principal questions: how much can reduce the hydrographic filed operations in remote sensing bathymetry and how much is the accuracy of waterbed topography extracting from satelite images? The result of our experiments showes that introducing of only one hydrographic line perpendicular to coastline as calibration data to ANN method is able to produce satisfied result with depth accuracy RMSE 1.6m and correlation coefficient $92 \%$.
\end{abstract}

Key words: Bathymetry, light attenuation physic, Satellite images.

Correspondence Address: Shariyati st, moalem st, National geographic organization(NGO), Tehran, Iran. Tel: +98 2188400111

Tel: +982161114256

Email: moj_ebrahimikia@yahoo.com 